Canadian Journal of Soil Science Revue canadienne de la science du sol

\title{
Soil organic carbon, nitrogen and phosphorus thirteen years after abruptly disturbing Northern Great Plains grassland
}

\begin{tabular}{|r|l|}
\hline Journal: & Canadian Journal of Soil Science \\
\hline Manuscript ID & CJSS-2016-0113.R1 \\
\hline Manuscript Type: & Short Communication \\
\hline Date Submitted by the Author: & 07-Nov-2016 \\
\hline Complete List of Authors: & $\begin{array}{l}\text { Thomas, Ben; Agriculture and Agri-Food Canada, Lethbridge Research and } \\
\text { Development Centre } \\
\text { Hao, Xiying; Agriculture and Agri-Food Canada, Lethbridge Research and } \\
\text { Development Centre } \\
\text { Willms, Walter; Agriculture and Agri-Food Canada, }\end{array}$ \\
\hline Keywords: & native grassland, cultivated, abandoned, land use change, wheat-fallow \\
\hline &
\end{tabular}

SCHOLARONE ${ }^{m}$

Manuscripts 
Soil organic carbon, nitrogen and phosphorus thirteen years after abruptly disturbing Northern Great Plains grassland

Ben W. Thomas, Xiying Hao*, Walter D. Willms

Agriculture and Agri-Food Canada, Lethbridge Research and Development Centre, 5403 - 1st

Avenue South, Lethbridge, Alberta, Canada T1J 4B1

* Corresponding author: xiying.hao@agr.gc.ca

Keywords: native grassland; cultivated; abandoned; land-use change; wheat-fallow

Short title: Soil organic C, N and P 13 yr after land-use change 


\begin{abstract}
:
Thirteen-years after cultivating native grassland and establishing continuous wheat (Triticum aestivum L.) and wheat-fallow rotations in southern Alberta, surface soil total $\mathrm{N}$ levels were $15 \%$ lower, and nitrate $(60-90-\mathrm{cm})$ concentrations were 2.5 - and 17 -fold greater, than native grassland. Wheat-fallow - even without fertilization - markedly enhanced potential nitrate loss through the root zone.
\end{abstract}


The first results of a study designed to assess the effect of abruptly altering the steady state condition of native grassland on soil properties were reported by Dormaar and Willms (2000). They found that $2 \mathrm{yr}$ after cultivating this grassland, soil organic $\mathrm{C}, \mathrm{N}$ and $\mathrm{P}$ were all significantly reduced. Five years after the grassland was cultivated, surface soil total $\mathrm{C}$ and $\mathrm{N}$ under the seeded perennial grasses were 30 and $25 \%$ lower than the undisturbed native grassland soil, respectively (Whalen et al. 2003). Thirteen years after cultivation, perennial grasses restored surface soil organic $\mathrm{C}$ storage to levels of the native grassland; whereas continuous wheat (Triticum aestivum L.) and wheat-fallow remained 20\% lower (Wang et al. 2010). While C has been the focal point of more research, uncertainty remains about how abrupt land-use change alters total N, P, and the depth distribution of soil nitrate $\left(\mathrm{NO}_{3}-\mathrm{N}\right)$ and soil-test $\mathrm{P}$ after decadal or more timescales in the Northern Great Plains of southern Alberta. Here, we present soil organic C, total N and P, nitrate and soil-test P concentrations $13 \mathrm{yr}$ after the initial cultivation in response to abandonment, perennial grass establishment, continuous wheat or wheat-fallow rotation to a soil depth of $90 \mathrm{~cm}$.

The research site was located at the Agriculture and Agri-Food Canada substation near Onefour $\left(49^{\circ} 07^{\prime} \mathrm{N}, 110^{\circ} 29^{\prime} \mathrm{W}\right)$ in southern Alberta, Canada. The site was undisturbed grassland consisting of a native Stipa-Bouteloua plant community on an Orthic Brown Chernozem (Aridic Haplustoll) soil with a clay loam texture. During the 13-yr study period (1994-2006) the mean annual precipitation of $329 \mathrm{~mm}$ was close to the $80 \mathrm{yr}$ mean of $331 \mathrm{~mm}$, and the mean annual temperature of $5.7^{\circ} \mathrm{C}$ was above the 80 -yr mean of $4.7^{\circ} \mathrm{C}$.

Treatment plots $(3 \times 10 \mathrm{~m})$ were established on previously uncultivated native grassland in spring 1994 by cultivating with a rototiller. The treatments were arranged in a randomized complete block design (RCBD) with four blocks. The seven treatments were (1) cultivated and then abandoned, leaving the plot to re-establish through succession from residual germplasm with no harvesting (abandoned); (2) cultivated and seeded with perennial monoculture of crested wheatgrass (Agropyron cristatum L. Gaertn.); (3) cultivated and seeded with perennial monoculture of Russian 
wildrye (Psathyrostachys juncea Fisch.); (4) annually cultivated continuous spring wheat (Triticum aestivum L.); (5) biannually cultivated spring wheat-summerfallow rotation (wheat-fallow); (6) a native community that was annually harvested (harvested grassland); and (7) a native grassland that was left undisturbed as a control (native grassland). The crested wheatgrass, Russian wild rye and spring wheat were seeded with $15-\mathrm{cm}$ row spacing. The experimental site was fenced to exclude cattle, deer and small herbivores. A 5-m buffer of was established between the fence and plots. Each year in early-May, the spring wheat treatments were cultivated using a Triple-K cultivator and packed with sheep's-foot packers, annually for continuous wheat and during the wheat year for wheat-fallow. The plots were seeded $\left(78.4 \mathrm{~kg}\right.$ seed ha $\left.{ }^{-1}\right)$ with a 3-point pony drill. In-crop weeds were controlled with selective herbicides and the wheat-fallow rotation was treated once with herbicide per fallow season (chemical fallow). Fertilizer and supplemental water were not applied. Since their establishment, all treatments were annually harvested (except for the undisturbed native grassland and the abandoned treatments - not harvested - and the wheat-fallow treatment - harvested every other year during the wheat year) with a forage harvester at a height of $8 \mathrm{~cm}$ at peak standing crop in early July or August. Crested wheatgrass was harvested about 1 mo earlier because of its earlier phenological development.

Soil samples were randomly collected from each plot using a $6.7-\mathrm{cm}$ diam. soil probe in early July 2006, which was the fallow year for the wheat-fallow rotation. Four samples were collected to a depth of $90 \mathrm{~cm}$ and divided into 0 to 15,15 to 30,30 to 60 and 60 to $90 \mathrm{~cm}$ soil layers. Coarse roots (>2 mm) were removed and soil samples were composited for each soil layer. Soil samples were then ground to pass through a 2-mm sieve for soil $\mathrm{NO}_{3}-\mathrm{N}$ and soil-test $\mathrm{P}$, while sub-samples were ground to pass through a $0.15-\mathrm{mm}$ sieve for total $\mathrm{C}$, inorganic $\mathrm{C}$, total $\mathrm{N}$, and total $\mathrm{P}$ determinations. Soil $\mathrm{NO}_{3}-\mathrm{N}$ was extracted with $2 \mathrm{~mol} \mathrm{~L}^{-1} \mathrm{KCl}(1: 5$ soil to $\mathrm{KCl}$ ratio) and its concentration determined with an automated colorimeter (AutoAnalyzer III, Bran + Luebbe, Germany). Soil-test P was determined using the Kelowna extraction method using a soil to extract ratio of 1:5 (Van Lierop 
1988). The soil total $\mathrm{C}$ and $\mathrm{N}$ concentrations were determined by dry combustion (Carlo Erba, Milan, Italy). Inorganic C was determined using a modified method of Amundson et al. (1998) and soil organic $\mathrm{C}$ was calculated as the difference between soil total $\mathrm{C}$ and inorganic $\mathrm{C}$. Soil total $\mathrm{P}$ concentrations were determined by digestion with $18 \mathrm{~mol} \mathrm{~L}^{-1} \mathrm{H}_{2} \mathrm{SO}_{4}$ (Parkinson and Allen 1975). The $\mathrm{P}$ concentration in the total $\mathrm{P}$ digest and the Kelowna extract (soil-test $\mathrm{P}$ ) were determined with an auto-analyzer (Astoria, Clackamas, OR, USA).

Statistical analysis was conducted with SAS 9.1 software (SAS Institute Inc. 2005). The UNIVARIATE procedure was used to check the residuals for normality and identify outliers. When an outlier was detected, it was removed before the final analysis was performed. All data were analyzed by one-way ANOVA as a RCBD with the MIXED procedure. Depth was a repeated measure. Means were compared by Fischer's protected LSD test at $\alpha=0.05$.

Soil organic $\mathrm{C}$ concentrations were significantly affected by the land-use change $(P=0.004)$, soil depth $(P<0.001)$ and land-use change $\times$ sampling depth $(P<0.001$; Table 1$)$. For the surface soil $(0-15 \mathrm{~cm})$, converting native grassland to continuous wheat or wheat-fallow reduced soil organic C by $23 \%$ compared with the undisturbed native grassland. Cultivating native grassland followed by abandonment reduced soil organic $\mathrm{C}$ by $11 \%$ compared with the native grassland, but abandonment led to $13 \%$ greater soil organic $\mathrm{C}$ than both wheat cropping systems. On the other hand, converting native grassland to perennial grasses or harvesting the native grassland did not significantly change soil organic $\mathrm{C}$ compared with the native grassland soil $13 \mathrm{yr}$ after cultivation. Even in absence of returning the aboveground residues, indicating that the belowground residues were primarily responsible for maintaining the soil organic $\mathrm{C}$ pool for the two perennial grasses and the harvested native grass treatments. For the 15 to $30 \mathrm{~cm}$ soil layer, the soil organic $\mathrm{C}$ concentration was $13 \%$ lower with continuous wheat than the native grassland, but no other differences were significant among land-use changes at the 15 to 30,30 to 60 or 60 to $90 \mathrm{~cm}$ depths. 
The soil total $\mathrm{N}$ concentrations were significantly affected by the sampling depth $(P<0.001)$ and sampling depth $\times$ land-use change $(P<0.001)$ but not land-use change alone $(P=0.069$; Table 1). In the 0 to $15 \mathrm{~cm}$ soil layer, the cultivated and abandoned soil had $8 \%$ lower total $\mathrm{N}$ than the native grassland soil, while the continuous wheat and wheat-fallow led to 7 to $15 \%$ lower soil total $\mathrm{N}$ than all other treatments (Table 2). In the 15 to $30 \mathrm{~cm}$ soil layer, wheat fallow led to $13 \%$ greater soil total $\mathrm{N}$ than continuous wheat. In the 30 to $60 \mathrm{~cm}$ soil layer, no significant differences among treatments were detected, while the wheat-fallow rotation had $13 \%$ less soil total $\mathrm{N}$ than the crested wheatgrass in the 60 to $90 \mathrm{~cm}$ soil layer, but no other differences were detected among treatments.

The soil total $\mathrm{P}$ concentrations were not significantly affected by land-use change $(P=0.913)$ or land-use change $\times$ soil depth $(P=0.613)$, but was significantly affected by depth $(P<0.001)$. The soil total P concentration was lowest from 15 to $30 \mathrm{~cm}\left(0.32 \mathrm{~g} \mathrm{P} \mathrm{kg}^{-1}\right)$, highest from 30 to 60 and 60 to $90 \mathrm{~cm}\left(0.40\right.$ and $0.42 \mathrm{~g} \mathrm{P} \mathrm{kg}^{-1}$, respectively) and between these values in the 0 - to $15-\mathrm{cm}$ soil layer $\left(0.35 \mathrm{~g} \mathrm{P} \mathrm{kg}^{-1}\right)$.

The soil $\mathrm{NO}_{3}-\mathrm{N}$ and soil-test $\mathrm{P}$ concentrations were significantly affected by land-use change, sampling depth, and land-use change $\times$ sampling depth (All $P<0.003$; Fig. 1). The soil $\mathrm{NO}_{3}-\mathrm{N}$ concentrations were disproportionately greater in the 30 to 60 and 60 to $90 \mathrm{~cm}$ soil layers with continuous wheat and wheat-fallow than the other treatments. The soil $\mathrm{NO}_{3}-\mathrm{N}$ concentration with continuous wheat was 6.3 -fold greater at 30 to $60 \mathrm{~cm}$ and 2.5 -fold greater at 60 to $90 \mathrm{~cm}$ than the native grassland and the wheat-fallow was 8.5 -fold greater at 30 to $60 \mathrm{~cm}$ and 17 -fold greater at 60 to $90 \mathrm{~cm}$ than the native grassland. Wheat-fallow led to 4.1 -fold greater soil $\mathrm{NO}_{3}-\mathrm{N}$ concentration at 60 to $90 \mathrm{~cm}$ than continuous wheat. The surface soil-test $\mathrm{P}$ concentrations were greatest with wheatfallow followed by the continuous wheat. There were minimal soil-test $\mathrm{P}$ differences among treatments within deeper soil layers.

Although the soil organic $\mathrm{C}$ was initially depleted in the fifth year after cultivation with every land-use change relative to the native grassland (Whalen et al. 2003), after $13 \mathrm{yr}$, the organic C levels 
were restored to the native grassland levels in most treatments except the continuous wheat and wheat-fallow rotation. As expected, there was higher soil organic $\mathrm{C}$, and total $\mathrm{N}$ concentrations in the surface soil, reflecting the higher plant biomass input near the soil surface through roots and aboveground biomass remaining after harvest $(<8 \mathrm{~cm}$ standing crop residue).

The soil organic $\mathrm{C}$ and total $\mathrm{N}$ concentrations in the surface soil for the abandoned treatment were 89 and $92 \%$ of those for the native grassland, respectively. Thus, 13 yr was insufficient to completely recover from the one-time intensive cultivation and removal of the aboveground biomass. Compared with the native grassland, $13 \mathrm{yr}$ of continuous wheat or wheat-fallow cropping resulted in $23 \%$ less soil organic $\mathrm{C}, 15 \%$ less total $\mathrm{N}$, but no significant difference in total $\mathrm{P}$ concentrations in the 0 - to $15-\mathrm{cm}$ soil layer, clearly demonstrating that continuous wheat or wheat-fallow affected soil organic $\mathrm{C}$ and total $\mathrm{N}$ concentrations more than total $\mathrm{P}$. Five years after cultivation, Whalen et al. (2003) reported that, soil total $\mathrm{C}$ was 38 and $39 \%$ and total $\mathrm{N}$ was 30 and $31 \%$, lower with continuous wheat and wheat-fallow, respectively, than the native grassland soil. Based on comparisons between 5- and 13-yr data, the soil organic $\mathrm{C}$ and total $\mathrm{N}$ gap between the soils cropped to wheat and the native grassland was reduced by about 16 and 15 percentage points. This provides evidence that some of the soil organic $\mathrm{C}$ and $\mathrm{N}$ lost with the initial disturbance was replenished with continuous wheat and wheat-fallow at similar rates even with annual and biannual cultivation. This is inconsistent with studies that have shown reduced fallow increased the rate $\mathrm{C}$ was sequestered in southern Alberta (Bremer et al. 2002; Smith et al. 2016), based on the similar apparent rate soil organic $\mathrm{C}$ and total $\mathrm{N}$ concentrations increased with both continuous wheat and wheat-fallow treatments in the 0 - to $15-\mathrm{cm}$ soil layer. This discrepancy may be explained by the initial breaking of the soil (Campbell et al. 1975; Woods et al. 2013) having a more significant impact on the recovery of soil organic $\mathrm{C}$ and total $\mathrm{N}$ than the annual or biannual cultivation of the continuous wheat or wheat-fallow over a 13-yr period. This implies that longer time scales may be required to observe differences in soil organic $\mathrm{C}$ and total $\mathrm{N}$ concentrations between continuous wheat and wheat-fallow. 
Similar total P concentrations with continuous wheat compared to the native grassland was similar to the results reported by Whalen et al. (2003). However, 5 yr after cultivation, the wheatfallow and the abandoned soil had 8 and $9 \%$ lower soil total $\mathrm{P}$ than the native undisturbed grassland, respectively (Whalen et al. 2003). After $13 \mathrm{yr}$, soil total P differences were no longer evident. This implies that the initial cultivation of this grassland reduced soil total $\mathrm{P}$ and the wheat-fallow and abandoned treatments restored soil total $\mathrm{P}$ levels between 5 and $13 \mathrm{yr}$ after initial cultivation.

A slight, but significantly higher total $\mathrm{N}$ concentration at 15 to $30 \mathrm{~cm}$ soil layer with wheatfallow than continuous wheat was probably because wheat-fallow was cultivated biannually instead of annually for continuous wheat. Biannual cultivation likely slowed mineralization of organic matter, leaving more total $\mathrm{N}$ (mostly organic N) in the fallow treatment (Six et al.1998). The significant accumulation of soil $\mathrm{NO}_{3}-\mathrm{N}$ outside the apparent root zone (30 to 60 and 60 to $90 \mathrm{~cm}$ soil layers) with continuous wheat and wheat-fallow indicates that converting grassland to these cropping systems increased the risk for plant-available $\mathrm{N}$ loss compared with the perennial grasses and the native grassland. In particular, the starkly greater soil $\mathrm{NO}_{3}-\mathrm{N}$ concentration at 60 to $90 \mathrm{~cm}$ depth with wheat-fallow than continuous wheat clearly shows that wheat-fallow retained significantly less soil $\mathrm{NO}_{3}-\mathrm{N}$ in the effective root zone (Fig. 1); even without fertilization. For a frame of reference, this is roughly the equivalent of $44 \mathrm{~kg} \mathrm{NO}_{3}-\mathrm{N} \mathrm{ha}^{-1}$ (measured bulk density of $1.42 \mathrm{~g} \mathrm{~cm}^{-3}$ ), whereby the ultimate fate is likely groundwater.

In conclusion, introducing perennial monoculture grassland restored soil organic $\mathrm{C}$ and total $\mathrm{N}$ to levels of the native grassland $13 \mathrm{yr}$ after cultivation and seeding. However, converting native grassland to a wheat cropping system significantly reduced soil organic $\mathrm{C}$ and total $\mathrm{N}$ concentrations. Cultivating native grassland followed by abandonment also led to lower soil organic $\mathrm{C}$ and total $\mathrm{N}$ concentrations than undisturbed native grassland, but abandonment led to smaller $\mathrm{C}$ and $\mathrm{N}$ losses than continuous wheat and the wheat-fallow rotation. The soil total P levels were restored as indicated by similar values for all land uses, and this indicates $\mathrm{P}$ is more resilient to land-use change 
than $\mathrm{C}$ and $\mathrm{N}$. Continuous wheat and wheat-fallow lost large proportions of soil $\mathrm{NO}_{3}-\mathrm{N}$ to the 60 to $90 \mathrm{~cm}$ soil layer, indicating that even without fertilization these land-use changes increased potential $\mathrm{N}$ loss through the root zone. 


\section{ACKNOWLEDGEMENTS}

This study was funded by Agriculture and Agri-Food Canada. We also acknowledge the financial support for Devin Goodsman from the Canadian Federal Youth Internship program. Special thanks to Devin Goodsman, Brett Hill, Pam Caffyn, Greg Travis and Ryan Beck for conducting field and laboratory work and Toby Entz for statistical analysis. We are grateful to the late Dr. John Dormaar for his role establishing the study site. 


\section{REFERENCES}

Amundson, R.G., Trask, J., and Pendall, E. 1988. A rapid method of soil carbonate analysis using gas chromatography. Soil Sci. Soc. Am. J. 52: 880-883.

Bremer, E., Janzen, H.H., and R.H. McKenzie. 2002. Short-term impact of fallow frequency and perennial grass on soil organic carbon in a Brown Chernozem in southern Alberta. Can. J. Soil Sci. 82: 481-488.

Campbell, C.A., Nicholaichuk, W., and Warder, F.G. 1975. Effects of a wheat-summer-fallow rotation on subsoil nitrate. Can. J. Soil Sci. 55: 279-286.

Dormaar, J.F., and Willms, W.D. 2000. A comparison of soil chemical characteristics in modified rangeland communities. J. Range Manage. 53: 453- 458.

Parkinson, J.A., and Allen, S.E. 1975. A wet oxidation procedure suitable for the determination of nitrogen and mineral nutrients in biological material. Comm. Soil Sci. Plant. Anal. 6: 1-11.

SAS Institute Inc., 2005. SAS OnlineDoc® 9.1.3. SAS Institute Inc., Cary, NC, USA.

Six, J., Elliott, E.T., Paustian, K., and Doran, J.W. 1998. Aggregation and soil organic matter accumulation in cultivated and native grassland soils. Soil Sci. Soc. Am. J. 62: 1367-1377.

Smith, E.G., Janzen, H., Scherloski, L., Larney, F.J., and Ellert, B. 2016. Long-term (47 yr) effects of tillage and frequency of summerfallow on soil organic carbon in a Dark Brown Chernozem soil in western Canada. Can. J. Soil Sci. doi: 10.1139/cjss-2015-0120

Van Lierop, W. 1988. Determination of available phosphorus in acid and calcareous soils with the Kelowna multiple-element extractant. Soil Sci. 146: 284-291.

Wang, X., Willms, W.D., Hao, X., Zhao, M., and Han, G. 2010. Cultivation and reseeding effects on soil organic matter in the mixed prairie. Soil Sci. Soc. Am. J. 74: 1348-1355.

Whalen, J.K., Willms, W.D., and Dormaar, J.F. 2003. Soil carbon, nitrogen and phosphorus on modified rangeland communities. J. Range Manage. 56: 665-672. 
Woods, S.A., Dyck, M.F. and Kachanoski, R.G. 2013. Spatial and temporal variability of soil horizons and long-term solute transport under semi-arid conditions. Can. J. Soil Sci. 93: 173191. 
1 Table 1 Effect of land-use changes (13 yr after establishment) and sampling depth on soil organic C and total N concentrations in a native Stipa-

2 Bouteloua community within the Mixed Prairie of the Northern Great Plains in southern Alberta.

\begin{tabular}{|c|c|c|c|c|c|c|c|c|}
\hline \multirow[b]{2}{*}{ Parameter } & \multirow{2}{*}{$\begin{array}{l}\text { Soil layer } \\
(\mathrm{cm})\end{array}$} & \multirow{2}{*}{$\begin{array}{c}\text { Native } \\
\text { Grassland }\end{array}$} & \multirow{2}{*}{$\begin{array}{l}\text { Harvested } \\
\text { Grassland }\end{array}$} & \multirow{2}{*}{$\begin{array}{l}\text { Russian } \\
\text { wildrye }\end{array}$} & \multirow{2}{*}{$\begin{array}{c}\text { Crested } \\
\text { wheatgrass }\end{array}$} & \multicolumn{3}{|c|}{ Continuous } \\
\hline & & & & & & Abandoned & Wheat & Wheat-fallow \\
\hline \multirow{2}{*}{ Organic C, $\mathrm{g} \mathrm{kg}^{-1}$} & $15-30$ & 7.96 a B & $7.65 \mathrm{ab} \mathrm{B}$ & $7.44 \mathrm{ab} \mathrm{B}$ & $7.43 \mathrm{ab} \mathrm{B}$ & $7.93 \mathrm{ab} \mathrm{B}$ & $6.93 \mathrm{~b} \mathrm{~B}$ & $7.80 \mathrm{ab} B$ \\
\hline & $60-90$ & 3.58 a C & $4.22 \mathrm{a} \mathrm{C}$ & 3.58 a C & $4.45 \mathrm{a} \mathrm{C}$ & $3.19 \mathrm{a} \mathrm{C}$ & $3.81 \mathrm{a} \mathrm{C}$ & $3.24 \mathrm{a} \mathrm{D}$ \\
\hline \multirow[t]{3}{*}{ Total N, $\mathrm{g} \mathrm{kg}^{-1}$} & $0-15$ & $1.54 \mathrm{a} \mathrm{A}$ & $1.44 \mathrm{ab} \mathrm{A}$ & $1.52 \mathrm{ab} \mathrm{A}$ & $1.52 \mathrm{ab} \mathrm{A}$ & $1.41 \mathrm{~b} \mathrm{~A}$ & $1.31 \mathrm{c} \mathrm{A}$ & $1.31 \mathrm{c} \mathrm{A}$ \\
\hline & $30-60$ & 0.84 a B & 0.83 a B & 0.85 a B & 0.85 a B & 0.81 a C & 0.86 a B & 0.77 a B \\
\hline & $60-90$ & $0.47 \mathrm{ab} \mathrm{C}$ & $0.52 \mathrm{ab} C$ & $0.50 \mathrm{ab} C$ & 0.53 a C & $0.45 \mathrm{ab} D$ & $0.50 \mathrm{ab} C$ & 0.46 b C \\
\hline
\end{tabular}

$3{ }^{a}$ Numbers in a row followed by different lower case letters indicate significant land-use change effect and numbers in a column followed by

4 different upper case letters indicate significant soil depth effect $(P<0.05)$. 


\section{$5 \quad$ Figure Captions}

6 Fig. 1. Soil $\mathrm{NO}_{3}-\mathrm{N}$ (a) and soil test $\mathrm{P}$ (Kelowna-extractable P) (b) concentrations 13 yr after abrupt

7 land-use change in the Northern Great Plains grassland of southern Alberta. For each soil layer, bars

8 with different lower case letters are significantly different $(P<0.05)$. Error bars indicate \pm standard

9 error. 
Figures

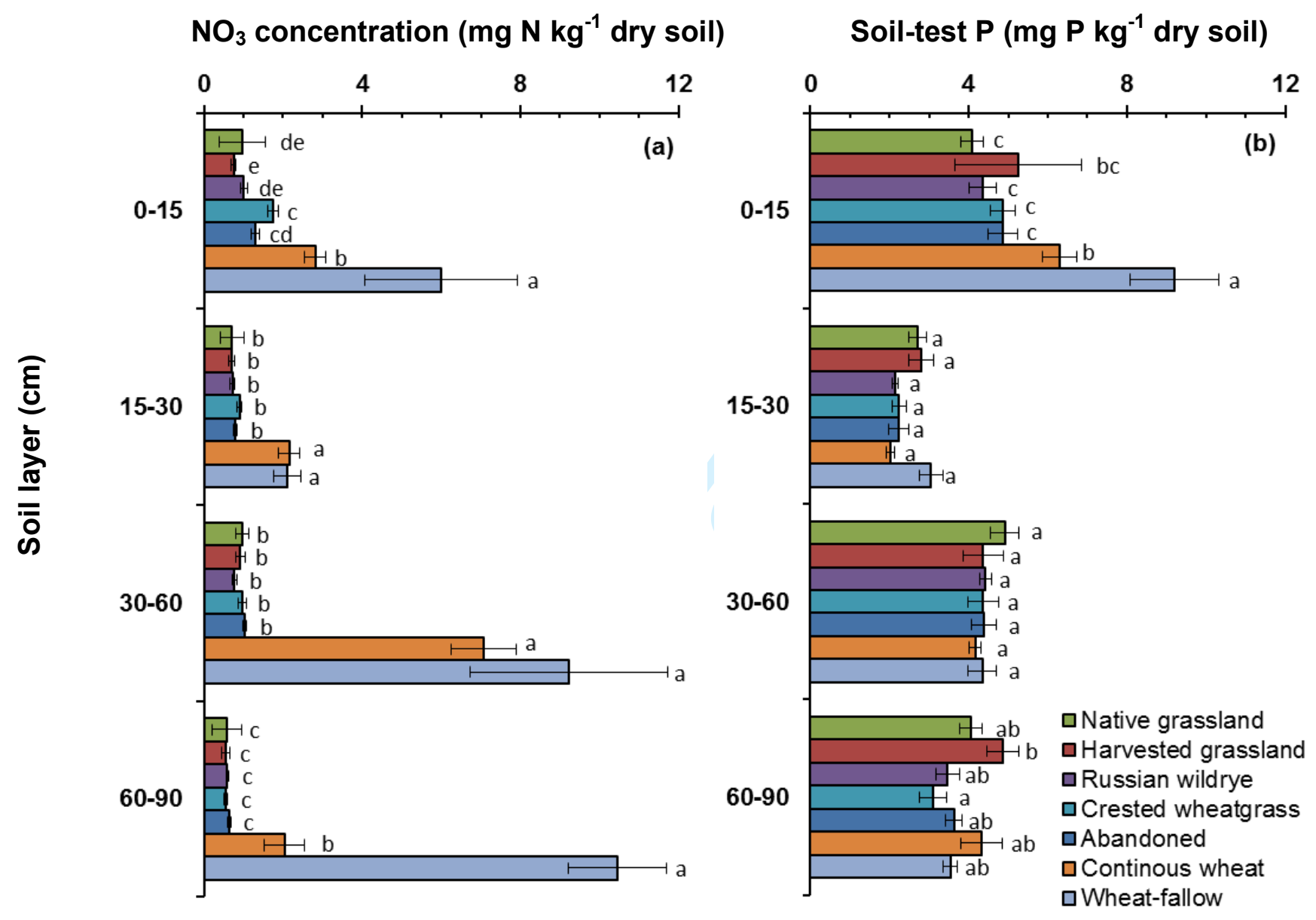

Figure 1 